\title{
THE SEEING EYE OF SCIENTIFIC GRAPHIC BIOGRAPHY
}

\author{
CANDIDA RIFKIND
}

Several recent graphic biographies tell the stories of the early days of nuclear research, from the discovery of radioactivity in the 1890s to the United States atomic bomb testings of the 1950 s. $^{1}$ Some are both celebratory and complex, such as Jim Ottaviani and Lelan Myrick's colorful Feynman (2011), a full biography of the larger-than-life American theoretical physicist, educator, and writer Richard Feynman. Ottaviani and Myrick use his famous Feynman Diagrams, which look like squiggly line drawings, as a motif throughout the book so that science meets art to depict the life of a man who thinks in pictures. In a quite different mode, Lauren Redniss's Radioactive: Marie \& Pierre Curie: A Tale of Love and Fallout (2010) is a double biography of the private and professional lives of this famous pair of chemists. Redniss incorporates cartoons, drawings, photographs, diagrams, and words into a visual-verbal collage of the discovery of radium. She also extends beyond the Curies' lifespans to depict how their discovery of radioactivity eventually led to theories of the nuclear atom, the development of the atomic bomb, the bombing of Hiroshima, and the nuclear accidents at Three Mile Island and Chernobyl. Nuclear history personalized through the lives of scientists is also the theme of two graphic biographies that focus on Robert Oppenheimer: Jim Ottaviani's collaboration with seven illustrators in Fallout: J. Robert Oppenheimer, Leo Szilard and the Political Science of the Atom Bomb (2001) and Jonathan Fetter-Vorm's Trinity: A Graphic History of the First Atomic Bomb (2012).

Both of these books depict the Manhattan Project, the United States government's research and development project "fathered" by Robert Oppenheimer. It ran from 1942 to 1947 and produced the first atomic bombs, tested initially at the Trinity desert site in New Mexico and then dropped on Hiroshima and Nagasaki. The style and focus of the two books vary, but they share the use of sequential visual-verbal narratives to reproduce the sequentiality of scientific experimentation. They both place Oppenheimer at 
the center of this story, but also deliver relational biographical narratives of a group of scientists. In this way, Fallout and Trinity are invested in Oppenheimer as a central cultural and political figure of the twentieth century, but also interested in how he is enmeshed in a larger scientific culture. They join a field of Oppenheimer scholarship that investigates the construction of the modern scientist as cultural hero, the militarization of scientific research, and the ethical discourses around technological advances and scientific progress. ${ }^{2}$ As graphic biographies, however, Trinity and Fallout draw as much on the visual forms of science education as they do on the narrative conventions of prose biography. In what follows, I explore how these works construct the figure of the scientist as a visual icon who is also a seeing subject. I propose that we consider scientific graphic biography as a specific genre that installs a biographical eye (as opposed to the auto/biographical I) to convey the complex relationship between empirical knowledge and affective experience that shapes lives caught between science and politics.

\section{ROBERT OPPENHEIMER AND THE SCIENTIFIC EYE OF GRAPHIC BIOGRAPHY}

Although both Trinity and Fallout are relational scientific graphic biographies, it is hard to overlook the prominence in both of Robert Oppenheimer, the "father" of the atomic bomb. Oppenheimer, along with Charles Darwin, Albert Einstein, and Marie Curie, is one of only a few modern Western scientists about whom we can say there is an extra-discursive field. ${ }^{3}$ There has always been a general interest in Oppenheimer as a public scientist. His work and persona fit the five traits Ray Goedell identified in 1975 as key to the prominence of public scientists: "being relevant (i.e., having a 'hot topic'), controversial, articulate, colorful, and credible" (Hecht 946). Moreover, Oppenheimer's role as a public scientist moved from pure science to social and moral commentary. As Lindsey Michael Banco explains, "Central to weaponizing atomic science, intensely committed to seeing his 'gadget' [Oppenheimer's own term for the atom bomb] deployed, and then later a vociferous opponent of nuclear arms proliferation, Oppenheimer plays a conflicted role in Cold War history, in decades of US foreign relations, and in emerging contemporary discourses concerning global terrorism" (493). As much as Oppenheimer may be remembered as the leader of the Manhattan Project, his name may also, for a smaller segment of the American public, invoke the hounding of suspected Communists and accusations of Soviet spying during the McCarthy era. Even in its barest biographical detail, Oppenheimer's life thus appears to be a classic tale of rise and fall, of loyalty and betrayal, of science compromised by politics. His blacklisting constitutes a tragic denouement to his life narrative, and complicates his status as genius-hero or American patriot. Although almost every 
prose biographer of Oppenheimer starts by admitting their subject's unknowability, there is a common narrative arc in Oppenheimer studies of his rise and fall. Ray Monk's celebrated recent biography, Inside the Centre, begins with an observation from Oppenheimer's good friend and colleague Isidor Rabi, who observed, he "was a man who was put together of many bright shining splinters ... who never got to be an integrated personality" (3). This comment is ideal for prospective biographers, of course, as it reinforces the complexity of their subject. I want to argue that this image of "shining splinters" is refracted in the graphic biographies as well, down to the very form of the divided panels and gutters. Oppenheimer's unknowability is, then, the very trait that makes him an ideal subject for graphic biography.

Graphic biographers are tasked with representing an absent real body on the surface of the page. Unlike the graphic autobiographer, who must synthesize her external and internal images of her self to produce her own caricature, the graphic biographer must create a pictorial icon of an other, a real person whose image often already circulates in photographs, films, drawings, and other visual forms. As numerous comics scholars have argued, the simplification of realistic detail into pictorial icons is a shorthand of identification and also an amplification of identity (McCloud 24-59; Hatfield 114-16). In Oppenheimer's case, his caricature varies across visual styles but he is recognizable for facial features historically associated in Western visual discourses with refinement: high forehead, prominent cheekbones, aquiline nose. In Figure 1, Fetter-Vorm introduces us to Oppenheimer for the first time by reproducing the effect of a snapshot portrait labeled with the text strip, "Brilliant" (22).

Figure 1. Snapshot portrait of Oppenheimer, from Trinity (22). Jacket Design and excerpts from TRINITY: A GRAPHIC HISTORY OF THE FIRST ATOMIC BOMB by Jonathan Fetter-Vorm. Jacket Design copyright (C) 2012 by Jonathan Fetter-Vorm. Copyright ( $)$ by Jonathan Fetter-Vorm and Michael Gallagher. Reprinted by permission of Hill and Wang, a division of Farrar, Straus and Giroux, LLC.

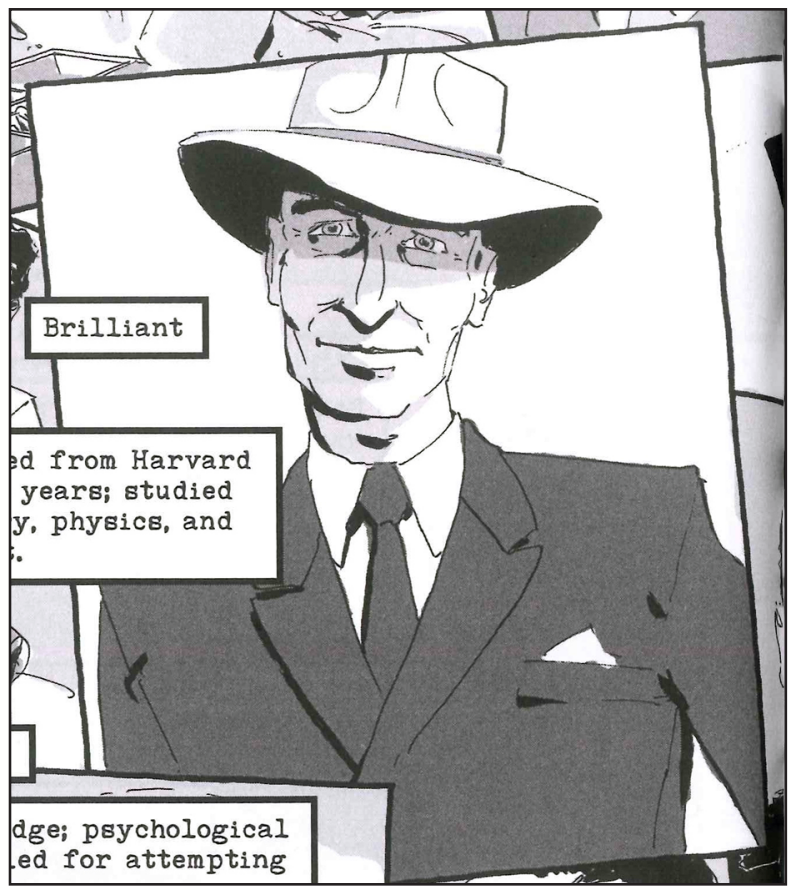


This visual portrait of a confident yet avuncular Oppenheimer draws him with the angular, almost gaunt physical features that fit with inherited visual icons of scientific genius. Patricia Fara attributes this visual tradition to the prominence of Godfrey Kneller's 1689 portrait of Isaac Newton as a "melancholy recluse" (72). She explains that, "because we have inherited Romantic stereotypes of genius, we attribute a thin, pale face, disheveled hair and fine fingers not to melancholy, but to mental brilliance" (72). Fara suggests that the descendents of this "detached Newtonian intellect with a minimalist body" are Sherlock Holmes and Stephen Hawking. To this list, I would add Oppenheimer, whose Newtonian body is in marked contrast in both graphic biographies to the hulking physicality of General Groves and the stocky solidity of Leo Szilard. This caricature that inherits portraiture's signs of mental brilliance also depends on Oppenheimer's "props": like Sherlock Holmes, Oppenheimer is usually depicted wearing a hat and with a pipe, occasionally a cigarette, in his mouth. Since Fallout is drawn by seven different illustrators, it contains multiple Oppenheimer caricatures marked at once by both consistency and variations. Figures 2, 3, and 4 show Oppenheimer rendered in the black-and-white styles of three different illustrators.

The biographical subject looks different as the narrative unfolds, but we still recognize him as a consequence of the reduced elements of caricature. The Newtonian body of the brilliant scientist reverberates in these three different caricatured images. As such, Fallout at once builds up a life narrative of Oppenheimer and reminds us that these are individual interpretations of the subject that we, the reader, must suture together into the illusion of a person whose isolated moments in each panel we construct into the temporal sequence of his life.

These caricatures of Oppenheimer demand a collaboration between cartoonist, text, and reader to produce a vision of the real person. How we see the subject(s) is a crucial element of graphic biography that distinguishes it from prose biography, which may use photographs to supplement its verbal portrait but does not move into the realm of visual caricature. Given the subject matter of these graphic biographies, the question of how we see Oppenheimer is related to how we see Oppenheimer seeing. As a modern scientist, Oppenheimer seeks visual proof for his theories, whether in the form of diagrams or atomic bomb test explosions. If autographics are, to quote Gillian Whitlock, "the seeing 'I' of the comics," then I propose that scientific graphic biographies give us the seeing eye of the comics. In both Trinity and Fallout, we see Oppenheimer gazing at two scenes in particular: the "empty" desert landscape prior to the test explosions and the image-event of the mushroom cloud explosion. Both of these graphic biographies rely on a common trope in Oppenheimer discourse that uses the desert landscape to stage the spectacle of 

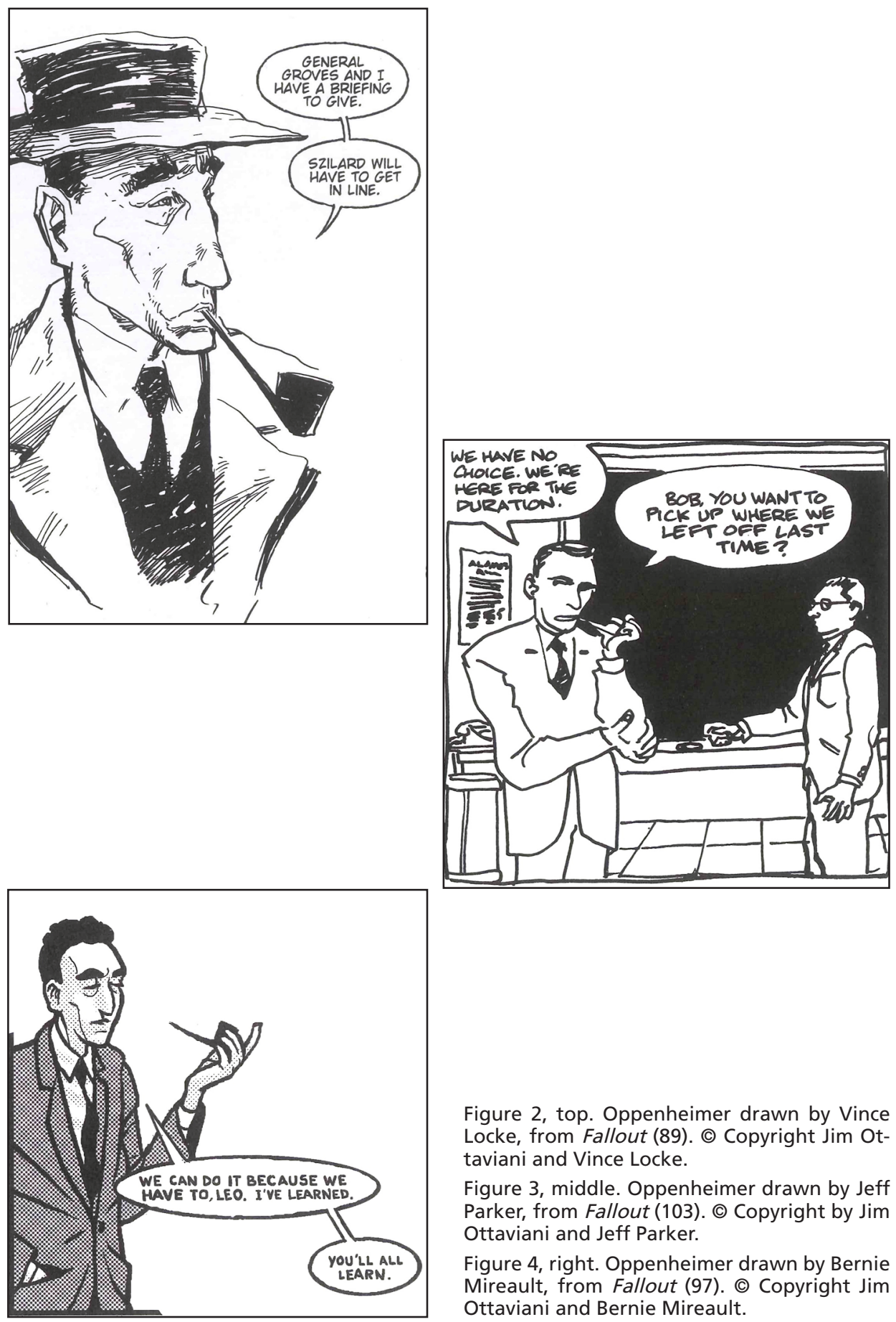

Figure 2, top. Oppenheimer drawn by Vince Locke, from Fallout (89). () Copyright Jim Ottaviani and Vince Locke.

Figure 3, middle. Oppenheimer drawn by Jeff Parker, from Fallout (103). () Copyright by Jim Ottaviani and Jeff Parker.

Figure 4, right. Oppenheimer drawn by Bernie Mireault, from Fallout (97). () Copyright Jim Ottaviani and Bernie Mireault. 
the first atomic explosion. As Banco argues in relation to prose biographies, Oppenheimer is invariably connected to the New Mexico desert and its dual nature as a practical, depopulated place to detonate the bomb and a surreal dream space that underscores the strangeness of the Manhattan Project. Both books repeat this trope visually in their paratextual material. The title page of Trinity is a drawing of the desert landscape, while the inside cover of Fallout is a pixilated photograph of a similar scene.

The image of the desert recurs throughout both graphic narratives. In Trin$i t y$, it is the backdrop to the third-person narrator's musings on why Oppenheimer chose his beloved horse-riding vacation region of New Mexico for the project: " . . maybe he sensed that the harsh, rocky vastness of a place like the American West was the only appropriate birthing ground for a force as elemental as an atomic bomb" (31). As such, and in keeping with Oppenheimer biographical discourse, the desert becomes an empty landscape, erased of $\mathrm{Na}$ tive American presence and ecological complexity, in which the white male scientist strives to achieve the American dream. As the narrator continues, "the Manhattan Project echoes an enduring American mythos: / that with enough money, hard work, open space, and inventiveness, anything is possible" (31). The desert setting that frames both of these graphic biographies becomes the scene of the key moment in Oppenheimer's life narrative, the Trinity explosion, but despite the iconicity of the mushroom cloud itself, each of the graphic biographies visualizes it quite differently.

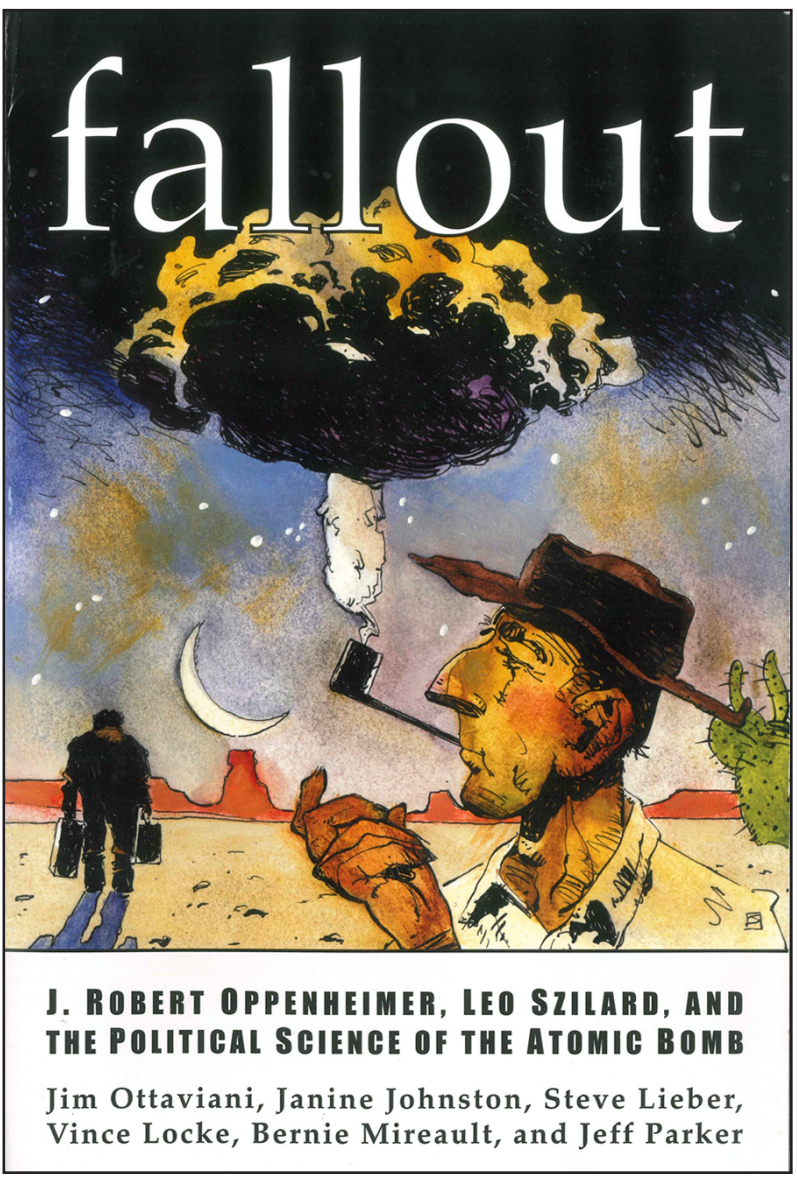

Figure 5. The cover of Fallout. @ Copyright Jeffrey Jones. 
The covers of both works depict the Trinity explosion in ways that highlight their different readings of Oppenheimer. Fallout depicts him as an almost folksy sage, sunburned and wearing his signature hat, the smoke from his pipe transforming into the mushroom cloud that he glances at sideways, almost nonchalantly (Figure 5). This image fits with the postwar mythologization of Oppenheimer as weathered cowboy that rendered him less threatening: "at heart he seemed a rugged individualist of the kind cherished in American mythology" (Hecht 952). This imagery, as much an outcome of Oppenheimer's self-fashioning as of admiring media reports, worked to reduce any suspicion of nuclear scientists as impractical, bumbling, book-loving types by placing him at home in the open air. In the bottom left, we see a
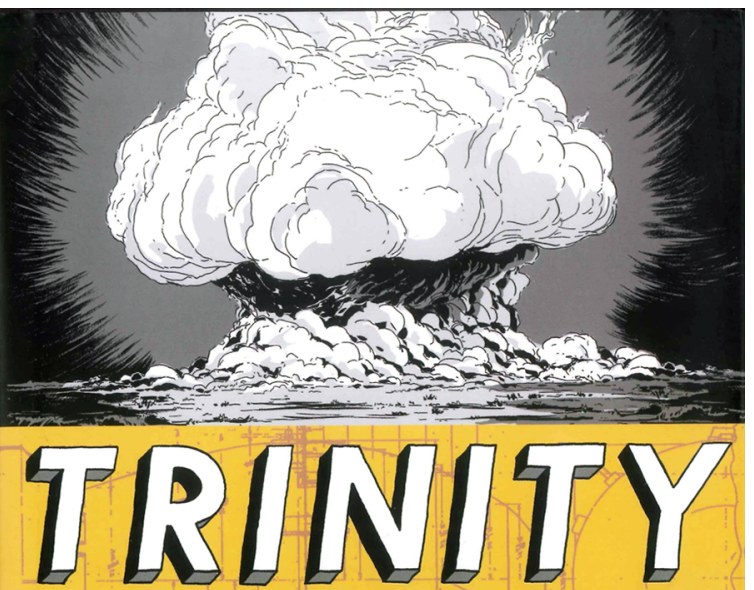

A GRAPHIC HISTORY OF THE FIRST ATOMIC BOMB

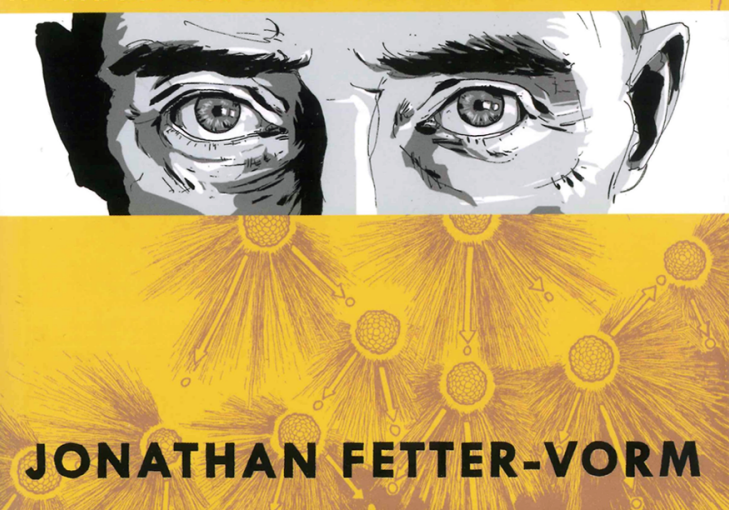

Figure 6. The cover of Trinity. Jacket Design and excerpts from TRINITY: A GRAPHIC HISTORY OF THE FIRST ATOMIC BOMB by Jonathan Fetter-Vorm. Jacket Design copyright (C) 2012 by Jonathan Fetter-Vorm. Copyright (c) by Jonathan Fetter-Vorm and Michael Gallagher. Reprinted by permission of Hill and Wang, a division of Farrar, Straus and Giroux, LLC.

with his suitcases: this is Oppenheimer's collaborator Leo Szilard, whose 1945 petition, signed by seventy of the scientists on the Manhattan Project, opposed the use of the atomic bomb on civilians, and led to his dismissal from Los Alamos by General Lesley Groves. So, this cover portrays several Oppenheimer myths: the scientist as rugged American folk hero; the betrayal by friends and colleagues; and the desert as romanticized natural setting for unnatural scientific activities. It is a quite benign image of Oppenheimer puffing the mushroom cloud out of his pipe when compared to the cover of Trinity where his brain seems to explode into the mushroom cloud (Figure 6). 
Here, the text strips divide the drawing of the mushroom cloud from Oppenheimer's gaze out at us, the reader, so that we watch him watching us watching the explosion. This is no portrait of a folksy sage, this is a much more ambiguous sequential image - it can be read vertically like a film strip running through a projector-in which Oppenheimer is either triumphant scientist or haunted moralist, or both. In this image, much more than in the other, Oppenheimer's gaze matters. To quote Banco again, "The scientific portrait of Oppenheimer frequently turns on the idea that the rational process of acquiring knowledge can be metaphorized in the scientist's privileged position surveying a vast stretch of landscape and looking at it with a penetrative gaze" (494).

The mushroom cloud exists because Oppenheimer led the group that created it, but also because Oppenheimer sees it: the scientific subject is the seeing subject, and in this case he sees something terrible and secret that portends unknown yet dire consequences (other people who saw it accidentally, such as some residents of Albuquerque, had no idea what they had witnessed). Both graphic biographies, in different ways then, draw the event of Oppenheimer's seeing as a form of witness to an image-event. They reproduce the mushroom cloud, a now-familiar pictorial icon, as an image-event, in Baudrillard's sense of not just an event become visible, but an event that exists in its becoming visible. The image-event at once "exalts" the event and takes it "hostage," multiplying it to infinity in its visual reproducibility but also serving as a diversion and neutralization of the real (Baudrillard). The Trinity explosion mushroom cloud is a much-studied twentieth century image-event that has multiple cultural meanings, both domestically and internationally. One of its central contradictions is that it is an image of mass death and also an image of procreation, a sign of the birthing of a new era and a figurative child of a marriage between "the scientific mind" and the "martial spirit" (Rosenthal 69). The familial language around Oppenheimer as "father" of the atom bomb is latent in this procreational reading of the image, and it follows him through his postwar parental concerns about the maturation of his scientific progeny beyond his control (Rosenthal 69). As the mushroom cloud image-event is seen, captured photographically (using specially designed technology), and reproduced visually in print and other media, it becomes the "real thing" of an event that happens so fast and is so sensorily overwhelming it seems unreal to many eyewitnesses (Rosenthal 80). Awe-struck, many eyewitnesses commented on the aesthetics of the explosion through comparisons to natural elements, from the sun to a flower to, most enduringly, a mushroom. ${ }^{4}$ In this way, the mushroom cloud is the atomic sublime: "a visual restorative that took terror and converted it back to beauty, took panic and transformed it to awe and admiration" (Hales 25).

In both graphic narratives, the impact of this image-event on Oppenheimer, the subject as moralist as well as scientist, is depicted in the realm 
of the sublime. Trinity draws Oppenheimer shielding his face from the light (Figure 7), cigarette in mouth like a film noir detective, saying the infamous lines he reportedly quoted from the Bhagavad Gita upon seeing the test explosion: "Now I am become death, the destroyer of worlds" (77).

My reference to the hardboiled detective here is deliberate: throughout, Trinity portrays Oppenheimer both visually and narratively as a tarnished hero establishing his own moral code in a modern world of violence and chaos. Once the bomb is used, the text interrupts its focus on Oppenheimer with three pages depicting Hiroshima on the ground. To do this, and to selfreflexively acknowledge that images of the horror are always mediated, FetterVorm draws a comics intertext. Trinity shows the experience of Hiroshima in silent splash pages of a suffering boy. This is a clear homage to, or even citation of, Barefoot Gen, Keiji Nakazawa's famous, decades-long, multivolume serial manga based on his own experiences as a survivor of Hiroshima.

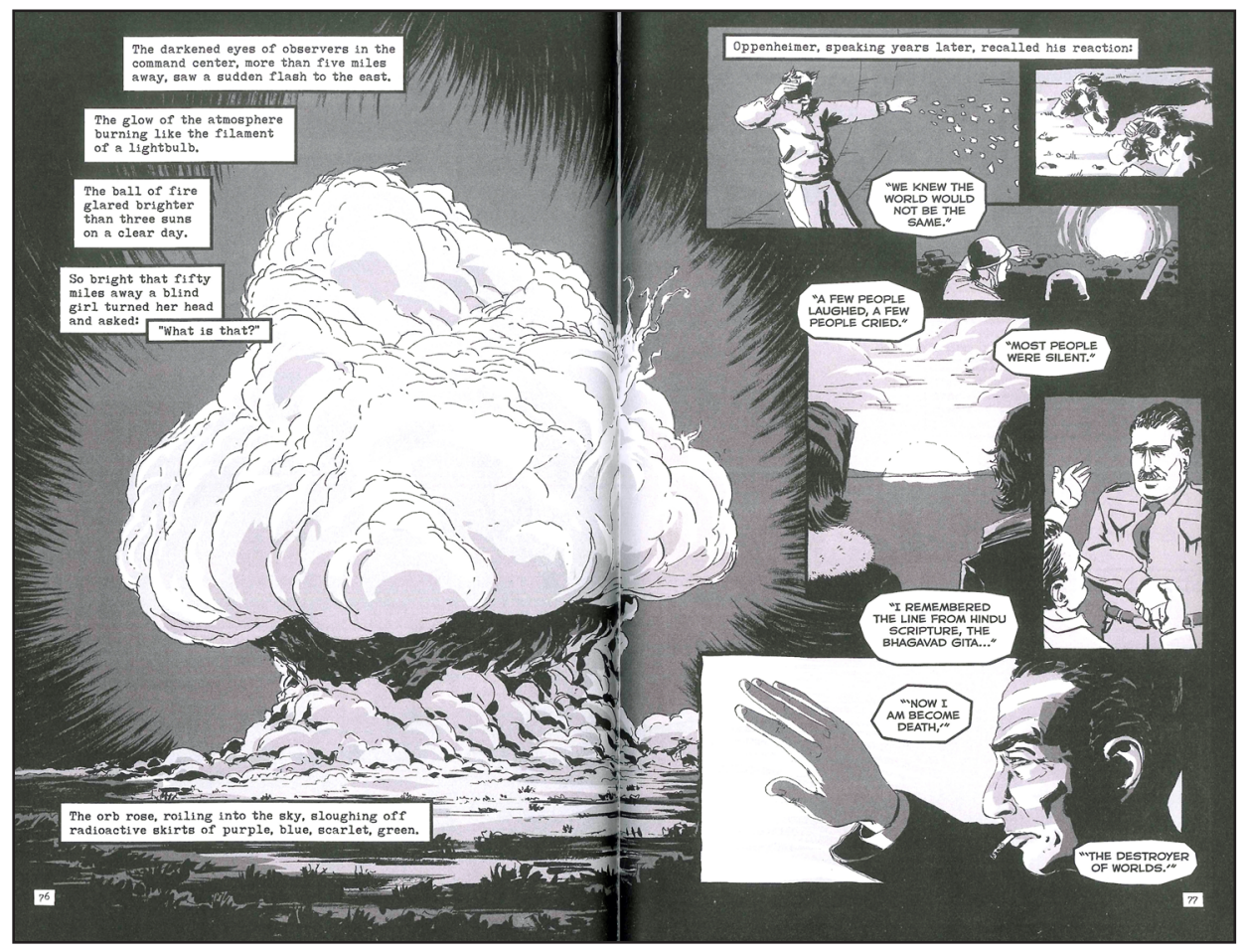

Figure 7. The Trinity explosion double page spread from Trinity (77). Jacket Design and excerpts from TRINITY: A GRAPHIC HISTORY OF THE FIRST ATOMIC BOMB by Jonathan Fetter-Vorm. Jacket Design copyright ( 2012 by Jonathan Fetter-Vorm. Copyright @) by Jonathan Fetter-Vorm and Michael Gallagher. Reprinted by permission of Hill and Wang, a division of Farrar, Straus and Giroux, LLC. 
In contrast, Fallout maintains a tight focus on Oppenheimer and mobilizes comics' potential for expressionism in ways that may or may not produce empathy for its subject. The explosion scene uses a splash page to sketch a diminished Oppenheimer in the midst of the cloud, looking at a photographic image of the many-armed god, Vishnu (Figure 8).

When this version of Oppenheimer looks at the image-event of the mushroom cloud, he sees beyond the real to the Hindu mythology of which he was a student. Fallout thus uses the visual to shape our understanding of Oppenheimer's interior life, so that we see the unreal that he sees through and beyond the real. In this way, Fallout shows the potential of graphic biography to use the ocular rather than the verbal to at once demystify and mystify the subject. It does not, however, shift its gaze from Oppenheimer to depict

Figure 8. The Trinity test explosion, from Fallout (139). (C) Copyright Jim Ottaviani, Janine Johnston, and Jeff Parker.

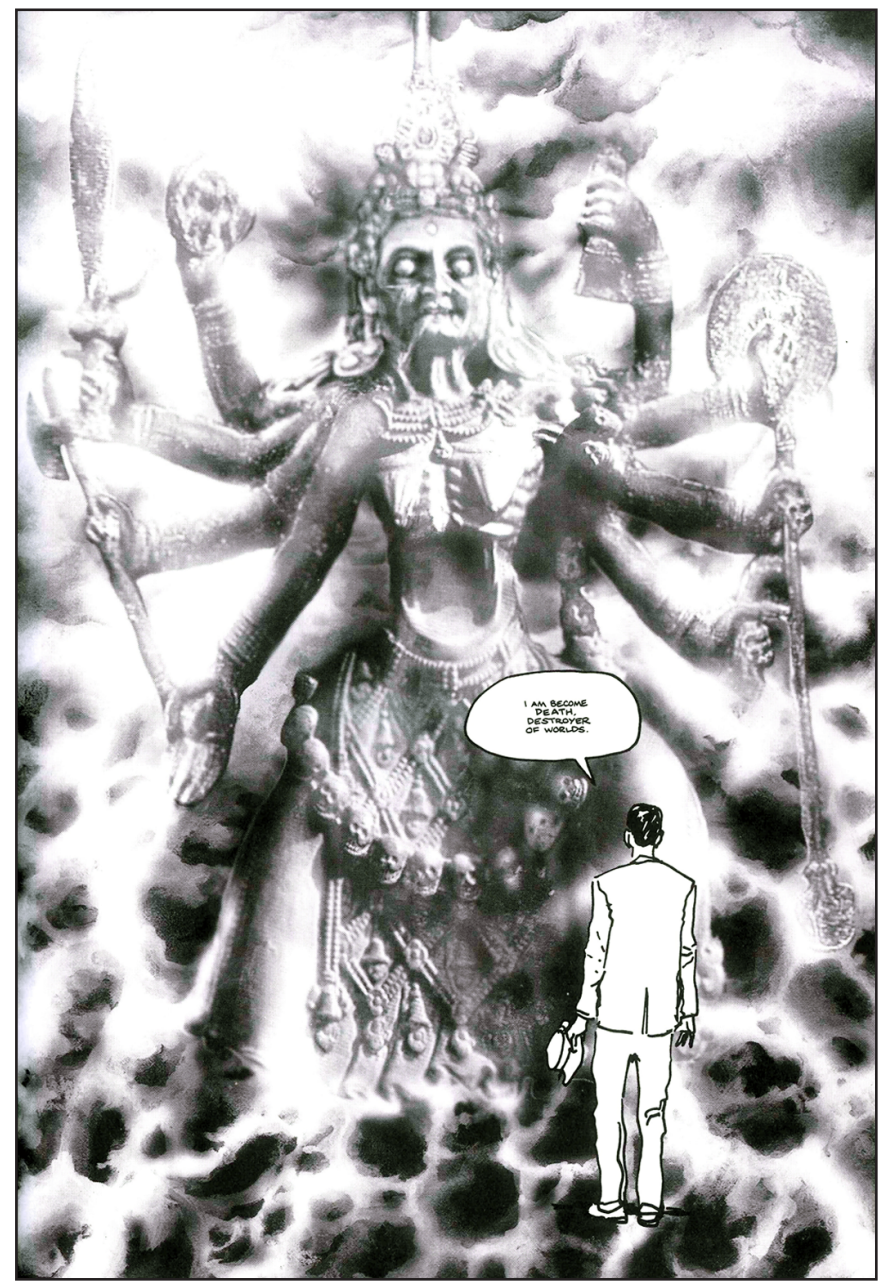


the impact of the bomb in Japan. The final chapter, titled "Fallout," is not about Hiroshima at all, but represents the political fallout of Oppenheimer's postwar opposition to continuing nuclear research. This tragic denouement produces the version of Oppenheimer as fallen, unjustly punished hero, an "American Prometheus," to quote the title of another prose biography.

\section{GRAPHIC BIOGRAPHY AND THE MANHATTAN PROJECT}

Full-length graphic biographies based on historical, visual, and other forms of research are a relatively new form of life writing. However, they reflect narrative, critical, and theoretical shifts in the larger field of biography. Sidonie Smith and Julia Watson explain that the past few decades have seen writers moving between autobiographical and more fictive forms "that make critical interventions in conventions of biographical narration" and can be understood as the "new biography" (8-9). This category is, in turn, being sub-divided in the scholarship to identify specific kinds of generic disruptions in such prose forms as metabiographies, antibiographies, and even pseudobiographies. Just as prose writers may experiment with practices that challenge conventional notions of biography, cartoonists can mobilize the specific techniques of their form for life narratives that move across individual and mass experiences, private intimacies and public performances. Biography and comics are both marked by instability. Biography merges fact and fiction to create the illusion of a coherent subject from the traces left behind by a real person; comics hybridize words and pictures to create the illusion of a whole narrative from many parts. They situate the reader between the presence of the page and the absence of the individual to demand our participation in closure-aesthetic closure of the gaps between panels and pages, and narrative closure of the gaps between events and experiences. The composite subject of graphic biography appears in a composite form, such that the biographical "truth" of the real person is always splintered.

The life stories of the physicists involved in the Manhattan Project are an ideal fit for this confluence of narrative and formal instability. This sub-genre of graphic biographies takes up a similar set of themes: the volatility of the split atom, the many unknowns about the explosions and radioactive fallout, the insecurity of the information even within the military compound at Los Alamos, and the split lives of many of the scientists, whether quite prosaically between home and work, or more urgently between European fascism and American refuge. The substance of these life stories is scientific, social, political, and psychological splintering. Thus, atomic graphic biographies triangulate instability, inserting it as a theme into a genre of partial knowledge (biography) and a form of fragments (comics). It may seem surprising that I categorize both Trinity and Fallout as graphic biographies when their subtitles 
cast them as different types of narratives. Trinity is sub-titled "A Graphic History of the First Atomic Bomb" and Fallout is sub-titled "J. Robert Oppenheimer, Leo Szilard, and the Political Science of the Atomic Bomb." As much as they may indeed be read as both history and political science respectively, I approach both of these comic books as graphic biographies because the larger histories of science and politics they trace are filtered through specific scientific personalities. This humanization of the intellectually and ethically difficult field of nuclear physics allows these cartoonists to represent their subjects' ideas and theories as well as their more intimate thoughts, feelings, and fears in ways that produce a very different understanding of the era and its events from conventional histories or political accounts. Drawing on the alternative comics tradition of stories that dwell on the experiences, anxieties, frustrations, and insights of individuals' mundane everyday lives, even when those lives are thrown into extraordinary circumstances, Ottaviani et al. and Fetter-Vorm construct scientific graphic biographies that leave behind the hagiographical tradition for a much more ambivalent take on individual achievement.

On the one hand, Trinity and Fallout both follow the "great man" biographical tradition in telling stories of famous white male subjects whose professional achievements have been written into a nationalist narrative of United States military and technological triumph. On the other hand, they both (albeit in different ways) harness the tropes and technologies of alternative comics to the practices of the "new biography." Janet Browne distinguishes between two types of prose scientific biographies: the traditional one that focuses on an individual's scientific and creative processes that lead to key discovery moments, and an alternate approach, emerging in the 1970s, that treats scientific knowledge as a social process in which collective lives become just as important as individual ones (348). Browne suggests that this latter approach interweaves the personal characteristics of individual scientists with each other and with their social, professional, and political institutions. As a result, "such forms of scientific biography can therefore provide historiographically significant space in which to explore institutional norms and the social expectations demanded of science" (349). In this way, both Trinity and Fallout are relational scientific biographies that reveal the balance between individual subjects and the historical forces that shape them.

Trinity uses an authoritative third-person narrator to tell atomic history as a relational biography of three main characters: Robert Oppenheimer (a theoretical physicist and Berkeley professor who was in charge of the Manhattan Project's secret weapons lab); Enrico Fermi (an Italian theoretical and experimental physicist who, with his Jewish wife, had escaped Italy in 1938); and General Leslie Groves (whose efficiency in overseeing construction of the Pentagon, both under budget and ahead of schedule, helped him get appointed as 
Director of the Manhattan Project). Other personalities appear as well to tell the story of Trinity as a series of collaborations and conflicts among scientists, the military, and politicians. The visual style is a clean monochrome palette that often juxtaposes facial close-ups with large-scale landscapes or magnified scientific drawings to create narrative tension. In an interview, Fetter-Vorm admits that the comics form allowed him to make such connections more easily than in prose, such that in the first few pages alone he can "draw a picture of the Greek myth of Prometheus alongside Marie Curie in her laboratory, followed by a schematic diagram of sub-atomic particles and already in the first few pages I've constructed a narrative about science, myth and history" (Wayne). While Fetter-Vorm does not attempt to reproduce or pastiche 1940 s comics styles, he does make some choices that evoke the period visually. The stark visual contrasts within and between panels, the numerous angled points-of-view, the retrospective voice of the narration rendered in typewriter font, and the period clothing combine to evoke the visual expressionism of classic film noir. Notoriously difficult to define as a genre, 1940s and '50s film noir is nevertheless a recognizable moody, disorienting visual style that reflects many of the films' portrayals of men and women confronted with moral dilemmas, deceptions, and betrayals. ${ }^{6}$ Fetter-Vorm's noirish expressionism may not reach the levels of Frank Miller's Sin City or other acclaimed fictional noir comics, but it does obtain a feel of the classic film noir's visual and thematic engagement with individuals compelled to act by circumstance who then fear exposure for their deeds.

The dominant story of Trinity ends in 1945 with President Truman ousting Robert Oppenheimer from future nuclear research because the scientist had begun to express publicly his anxieties about continuing to develop and detonate atom bombs. Fetter-Vorm then offers an Afterword in which the panels move scene-to-scene over the abandoned Trinity test site in New Mexico as the narrator ponders the irony that "this atomic force is a force of nature" that "will outlast our dreams" (151). It is a final narrative statement at once mystical and melancholy, and it allows the text to end with a sense of foreboding arising from the sublimity of atomic power itself. In this way, Trinity foreshortens the life narrative of its main scientist, Oppenheimer, so that the personality helps the text to examine the details and contexts of the science but the science does not help to examine the life. This is not a cradle-to-grave individual biography as in Feynman. Rather, it is a relational humanizing of the Manhattan Project that uses the scientific personalities to stage the conflict between theoretical knowledge and military technology. Oppenheimer emerges as the kind of male protagonist familiar from film noir for his ultimate alienation from social and state institutions and his final recognition of the downward and inescapable spiral into which he has fallen. He is a modern man who is haunted by modernity. 
Fallout shares many of Trinity's personalities, events, and visual references, but it is an altogether looser and less didactic graphic narrative of the Manhattan Project. Fallout tells the story of the Manhattan Project as a double biography of Oppenheimer and Leo Szilard, a Jewish Hungarian physicist. Szilard traveled to London in the early 1930s, conceived of the nuclear chain reaction in 1933, and moved to the United States in 1938. Once there, Szilard wrote the letter to President Roosevelt in 1939—co-signed by Albert Einstein to lend it weight - that explained the potential for Germany to develop nuclear weapons. The letter was effective, and Szilard's warning led to the creation of the Manhattan Project. Unlike Trinity, this book is an artistic collaboration. Writer Ottaviani challenges the notion of authoritative representations of these protean and complex real people, and the volatile and mysterious subject of atomic science, in his decision to work with seven illustrators, all of whom have distinct black-and-white visual styles. For instance, there is the illustrative soft pencil style of Janine Johnston's "Birth" section about Szilard's breakthroughs in London, the ratty comix style of Jeff Parker's "Work" section about the Trinity test, and the halftone dots and computer enhancements of Bernie Mireault's epilogue about Szilard dying of cancer in the 1960s. As a consequence, the same people look different as the narrative unfolds. This reminds us that we are at once being invited into an intimate portrait of secret science and that every portrait is partial, both limited and particular. The book covers approximately thirty years of nuclear research and global politics to narrate a relational scientific biography. It concludes in 1960 at Leo Szilard's hospital death-bed. In this final scene, Szilard tells his former colleague, Hans Bethe, that he is going to write a memoir of the Manhattan Project, declaring "I am just going to write down the facts—-not for anyone to read, just for god." Bethe responds, "Don't you think god knows the facts," and Szilard gets the last words of the book: "Maybe .. . / But not this version of the facts" (207).

This metatextual exchange repeats the text's ongoing concern with the blurred lines between truth and fiction. It reaches a crescendo in the lengthy post-Manhattan Project chapter, "Death," that depicts Oppenheimer's 1954 United States government investigation for putative Communist sympathies. This story, which comprises the "political science" of the book's subtitle, takes up the final fifty pages of the narrative in an interesting visual and verbal composition of government letters and court transcripts about Oppenheimer's leftwing sympathies, run in vertical typescript columns alongside comics sequences depicting the present of the government investigation and flashbacks showing the events to which Oppenheimer is testifying. A wordless sequence at the end of the chapter zooms in on Oppenheimer's hands opening an envelope containing his redacted statements and his Los Alamos security clearance card cut in half. The bottom panel zooms up to a high angle shot of Oppenheimer sitting 
on the edge of a bed, documents strewn around him, presumably absorbing his exile from government-sponsored nuclear research (201). This private scene of his professional blacklisting personalizes the political science of the graphic narrative, and humanizes the early 1950s convergence of US military investment in ongoing atomic testing and US government fears of Communist infiltration by some of the very people who pioneered its nuclear program.

As in Trinity, the lives of Oppenheimer and his coworkers function as narrative vehicles to convey complex scientific and political developments. Oppenheimer's professional exclusion is rendered as a tragic fate befitting a modern mid-century male protagonist. Unlike Trinity, however, Fallout takes greater formal risks in its visual-verbal experimentations with reproducing official discourse as part of cartoon representations of historical events. Trinity's visual commitments to a noir style produce a consistent version of Oppenheimer and the other men appropriate to their time period that also layers them with the affective registers of a cinematic movement infused with anxiety, fear, and foreboding. Fallout's diverse visual styles and verbal-heavy sections displace the multiple biographical subjects from any particular feel of the historical period. This text moves between twentieth century styles that are also ideologically and culturally inflected. Fallout oscillates between chapters in the Clear Line style associated with pre-World War II cultural and political certainty, ratty or rough comix style chapters that evoke the $1960 \mathrm{~s}$ youth and underground culture's challenges to those certainties, and a late twentieth-century computer generated style that highlights challenges to the very role of the artisanal hand-drawing cartoonist in the contemporary era. Formally, then, this graphic narrative is uncertain about singular versions of life narratives and the truth-claims of any one version of the Manhattan Project. This repeats Ottaviani's thematic investments in multiple and competing versions of what happened at the levels of both science and politics.

Despite their stylistic differences, both books share the use of paratextual material to trouble biography's rhetorical illusion of empirical knowledge about a coherent subject (see Bourdieu). In Trinity, the authority of the omniscient third-person narration is supported by a bibliography to refer readers to various research sources on Oppenheimer and the Manhattan Project. As well, Fetter-Vorm undertook extensive archival photographic research to depict the Manhattan Project and the explosion over Hiroshima and its aftereffects (Wayne). Nevertheless, his Author's Note admits that when no written records were available to adapt to scenes in the graphic narrative, he "introduced language that hews closely to what I have learned of these characters over the course of my research" (153). Not only does the line between recorded and imagined events get blurred, but in this statement the cartoonist betrays the importance of personality to his historical narrative. Fallout goes 
further in asserting the factuality of its narrative by supplementing an annotated bibliography with detailed paratextual endnotes to point to the authoritative sources on which this text relies. At the same time, Ottaviani makes no pretense of the fictional nature of his factual story. This is clear from the very beginning, in the epigraph to Fallout titled "Science Fiction": "Though not a work of history, this book isn't entirely fiction either. We've fabricated some details in service of the story, but the characters said and did (most of) the things you'll read. And as the notes and references will indicate, many of the quotes and incidents that you'll think most likely to be made up are the best documented facts" (n. pag.). Using the second person to anticipate the reader's incredulity at the content of this relational graphic biography, Ottaviani at once assures the reader of his authority and highlights the strangeness of the Manhattan Project story and the extraordinariness of its personalities.

Both of these graphic scientific biographies are representations of a particular version of the facts of early atomic science, and they are both in different ways explicit about the gaps and limits in their knowledge. The juxtapositional possibilities of the comics form allows these texts to negotiate visually the central challenge of prose scientific biographies, namely how to narrate the life story while communicating the significance of the individual's scientific discoveries. As much as both texts make claims to authoritative knowledge through endnotes and bibliographies, they also admit to having to invent some dialogue and imagine some scenes. This compromise between documentary and fiction produces a balance of science and art in showing the life stories and strange histories of early atomic science.

\section{CARTOON SCIENCE AND NUCLEAR DIAGRAMS}

The majority of graphic biographies tells the stories of someone renowned for public or professional endeavors, and so they must not only tell the life story but they must find ways to represent visually the activities for which that person is well known. In her discussion of Darwin biographies, Browne asks a fundamental question about all scientific biographies: "How should a writer deal with those parts of a person's mental life that may be hard to understand or too abstract for the projected audience? Should a book be written with the science left out?" (348). Given the difficult nature of even the basic aspects of nuclear physics, this is a pressing problem for Oppenheimer biographers. However, comics has an advantage over prose: it can reproduce the visualverbal form of science diagrams within its sequences. Trinity and Fallout thus both exploit the visuality of scientificity. This rather ungainly term refers to the idea, first proposed by science sociologist Bruno Latour in his "graphism thesis," that distinctions between hard and soft sciences correlate to the use 
of graphs and diagrams. Diagrams fall into the category that science communications scholars since Latour have often called "inscriptions."7 On a basic level, this term refers to visual images used in scientific publications and popular media, ranging from photographs and maps, to tables, graphs, equations, and diagrams. On a more conceptual level, inscriptions are, to quote one recent study, "the crucial elements of the material culture by which knowledge claims are negotiated and renegotiated until they emerge, in refined form, as the published 'facts' of science" (Arsenault et al. 378). Diagrams are not the real thing; they are a consensual visual representation of the thing believed to have taken place. The prevalence of inscriptions produces the visuality of scientificity-the notion that the harder the science, the more "sciency" the field, the more it depends upon visual rather than verbal explanations (Arsenault et al.). Nuclear science is very hard, and so, perhaps counterintuitively, it lends itself to cartooning.

Scientific graphic narratives often incorporate inscriptions, and diagrams of various stages of early nuclear physics are a striking feature of both Trinity and Fallout. Since there are many throughout both books, I will focus here on representations of the chain reaction of fission, which was the scientific breakthrough necessary to turning the experiment into a bomb. In Trinity, Fetter-Vorm uses an inset panel of two scientists, Szilard and Fermi, using a blackboard to discuss the problem (Figure 9).

The rest of the page works without gutters, but the text strips move the

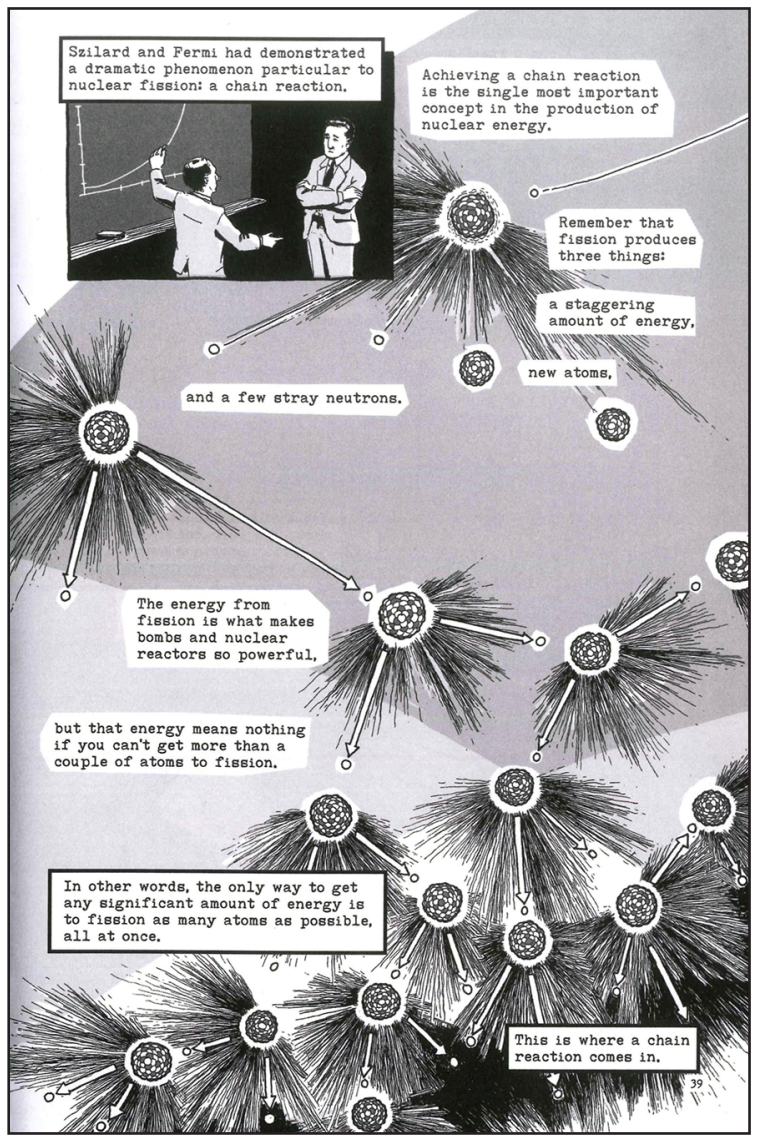

Figure 9. Szilard and Fermi discuss nuclear fission, from Trinity (39). Jacket Design and excerpts from TRINITY: A GRAPHIC HISTORY OF THE FIRST ATOMIC BOMB by Jonathan Fetter-Vorm. Jacket Design copyright (C) 2012 by Jonathan Fetter-Vorm. Copyright (C) by Jonathan FetterVorm and Michael Gallagher. Reprinted by permission of Hill and Wang, a division of Farrar, Straus and Giroux, LLC. 
reader from top to bottom, explaining verbally what the visuals illustrate. The absence of gutters does not always mean the absence of sequentiality, and the words and pictures work together to walk us through the stages of a chain reaction. Fetter-Vorm's drawing of the diagram in Trinity adapts it from scientific textbooks but also recirculates it from within the world of comics. A decade earlier, Fallout presented a very similar page layout for its representation of the diagram of a nuclear chain reaction. In Figure 10, we see two inset panels (top left) representing Leo Szilard as he walks around 1930s London conceiving of a nuclear chain reaction through the visual metaphor of
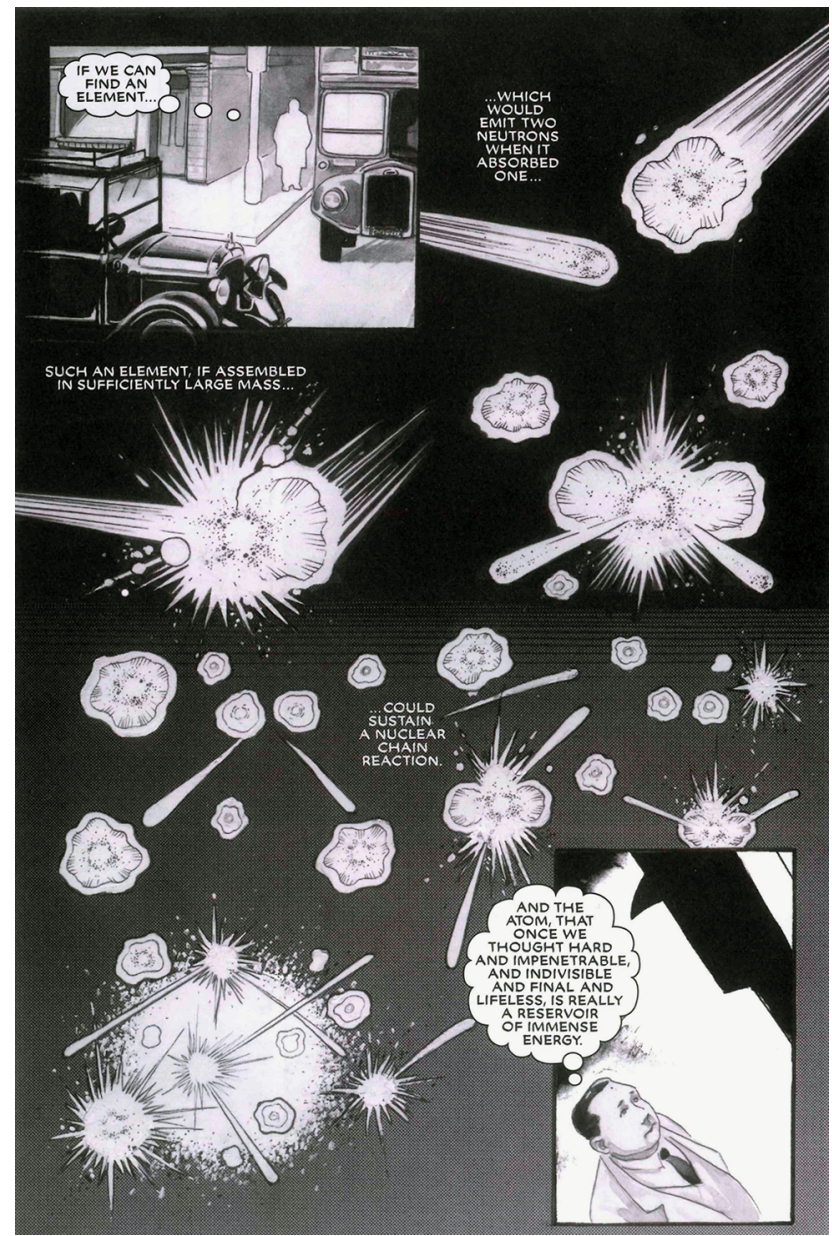

Figure 10. Szilard imagines a nuclear chain reaction, from Fallout (28). () Copyright Jim Ottaviani and Janine Johnston. an astronomical collision.

The page layout exploits the unique ability of comics to take us inside the character's mental visualization as he verbalizes his thoughts, allowing us to see the scientist and the science at once. It thereby resolves one of the central organizational challenges of prose scientific biographies, which must often choose between chronological narration of the subject's life or thematic narration of their discoveries (Söderqvist 242). In both of these graphic narratives, the cartoonists combine the grammar of comics with the communications of science so that the form not only conveys but embodies the content. This is a different use of diagrams from that typical of educational publications and science 
textbooks because these graphic narratives use verbal narration by personalities within visual representations to move us through the sequential steps of the experiments as the page visualizes the theory.

On the one hand, the cartoonist's adaptation of a scientific diagram is similar to drawing a photograph of his biographical subjects: we are aware that a prior image exists, perhaps one that is taken to be more realistic or authentic than the cartoon version. On the other hand, atomic scientific diagrams are different from photographs, since they represent theories of how the experiment worked rather than an image of the experiment itself. In her discussion of prose scientific biographies, Browne suggests that modern science depends upon a separation between "objective and universal" facts and theories and the individuals who proposed or explained them (350). Biography, then, "can explore this process of separation and try to catch the process of objectification in action" (350). These fission diagrams refuse the separation Browne identifies as fundamental to the "abstract nature of science" (350) by re-placing the scientist inside the theory represented as a visual diagram.

As much as graphic biographies can draw on science textbooks as an enabling device, though, diagrams may be as puzzling as they are clarifying. In a brief essay titled "On the Graphic in Postmodern Theoretical Writing," Rey Chow draws on Michel Foucault and Roland Barthes to think about the proliferation of graphs, charts, and other diagrams in contemporary theory-from Jacques Lacan's bars to Fredric Jameson's semiotic squares to Gilles Deleuze's vectors-as forms of scientific graphicity that give abstract thoughts objectifiable shapes. The problem, she notes, is this: "Offering the semblance of positivity and universality, the graphic is simultaneously cryptic and enigmatic, its readily visible forms impenetrable even to sophisticated readers, who are typically at a loss as to what it means without detailed explanations, without the help of words" (377-78). As a result, she concludes, "the graphic figures serve in effect as a little theater where the unresolved relationship between words and things perpetuates itself in the manner of a spectacle" (378). Chow's discussion of a different use of diagrams in relation to words works well for thinking about these scientific graphic biographies and their use of scientific inscriptions: the diagrams do not resolve the limits of verbal scientific description; rather, they dramatize, or perhaps spectacularize, competing systems of knowledge production and communication, drawing the science into the life without promising absolute clarity for either. In this way, Trinity and Fallout spectacularize science through diagrams that re-enact the central visual/verbal tension of comics itself. Even though comics are often described as a hybrid of words and images, the two sign systems or codes are neither as distinct as they may seem (words can be rendered pictorially; pictures can contain words) nor as seamless as we may wish (they may play against each other). The visual/verbal tension that is 
one defining feature of comics, then, "may be characterized as the clash and collaboration of different codes of signification" (Hatfield 41; emphasis in original). My point here is not that inscriptions are better or more accessible representations of scientific thought than words. Rather, the drawing of inscriptions in scientific graphic biography highlights the picture-thinking of these personalities, and dramatizes the very process of objectifying personal thoughts and interpersonal exchanges into the "facts" of nuclear science.

Trinity and Fallout thus show how graphic biography, when it plays with the page as a surface onto which we project our desires to understand an other, may produce a sequential refusal of biography's rhetorical illusion of a coherent, unified subject. While both texts make claims to authoritative knowledge about the subject and the period, they also admit to having to fill in gaps in biographical and historical knowledge, just as the reader must perform closure between the panels. As much as we may want to read scientific graphic biographies as parallel texts to scientific prose biographies, I hope to have suggested here the fruitfulness of seeking an alternate comparative field: educational science texts that depend upon graphicity as much as verbal literacy. The confluence of cartooning and scientific inscriptions to personalize nuclear physics allows these comics to negotiate visually the central challenge of prose scientific biographies, namely how to narrate the life story while communicating the significance of the individual's scientific discoveries. The form of comics also allows the cartoonists to push beyond biographical realism into, for instance, expressionism to show what Oppenheimer saw in his mind's eye, or intertexuality to show that which Oppenheimer could not, would not, see. In both of these texts, however, neither diagrams nor departures from the truth-claims of history and political science can resolve the problem of the subject's ultimate unknowability. Instead, the fragmented form of comics becomes a suitable form in which to represent the splinters of this narrative and to marry alternative comics with the "new biography." As such, and in different ways, Trinity and Fallout produce, at best, half-lives of Robert Oppenheimer. And in turn, the formal aesthetics of these works suggests, in different ways, the danger of the Manhattan Project's own penetrative desire for pure knowledge, its illusionary faith that seeing and knowing are the same thing.

\section{NOTES}

AUTHOR'S NOTE: this article benefitted from feedback to two earlier versions I presented at the Visual/Verbal Texts Symposium at the University of Winnipeg in June 2013 and the International Auto/Biography Association (IABA) conference at the Banff Centre in May 2014. I am also grateful to James Hanley, my colleague in the Department of History at the University of Winnipeg, for his help in navigating the complex history of early nuclear physics and The Manhattan Project. 
1. See Szasz for a survey of twentieth century fictional and educational comics that played a pivotal role in establishing the place of atomic science in the US cultural imagination.

2. See Banco, Carson and Hollinger, Hecht, and Thorpe.

3. I borrow this term from William Epstein's description of Marilyn Monroe's extra-discursivity (223). Like Monroe, Oppenheimer has been the subject of numerous prose biographies and has appeared in films, plays, operas, and fictionalizations, such that he is a subject within creative and critical discourse.

4. See Rosenthal and Weart for critical analyses of the term "mushroom cloud."

5. Hijiya explores the full implications of Oppenheimer's legendary quoting of the Gita at this moment.

6. My understanding of film noir draws on Borde and Chaumeton's classic study and Naremore's analysis of both the films and their construction in cultural memory.

7. Latour and Woolgar's classic study, Laboratory Life: The Social Construction of Scientific Facts, describes the value laboratory scientists ascribe to inscriptions as having a direct relationship to the original substance or matter they depict.

\section{WORKS CITED}

Arsenault, Darren J., et al. "Visual Inscriptions in the Scientific Hierarchy: Mapping the 'Treasures of Science."' Science Communication 27.3 (March 2006): 376-428. Print.

Banco, Lindsay Michael. "The Biographies of J. Robert Oppenheimer: Desert Saint or Destroyer of Worlds." Biography 35.3 (Summer 2012): 492-515. Print.

Baudrillard, Jean. "The Spirit of Terrorism." Le Monde

Borde, Raymond, and Etienne Chaumeton. A Panorama of Film Noir 1941-1953. London: Wallflower, 2002. Print.

Bourdieu, Pierre. “The Biographical Illusion.” Trans. Yves Winkin and Wendy Leeds-Hurwitz. Identity: A Reader. Ed. Paul du Gay et al. London: SAGE, 2000. 297-303. Print.

Browne, Janet. "Making Darwin: Biography and the Changing Representations of Charles Darwin." Journal of Interdisciplinary History 40.3 (Winter 2010): 347-73. Print.

Carson, Cathryn, and David Hollinger, eds. Reappraising Oppenheimer: Centennial Studies and Reflections. Berkeley: U of California P, 2005. Print.

Chow, Rey. "On the Graphic in Postmodern Theoretical Writing." Twentieth Century Literature 57.3-4 (Fall-Winter 2011): 372-79. Academic OneFile. Web. 23 July 2014.

Epstein, William H. "(Post)Modern Lives." Contesting the Subject: Essays in the Postmodern Theory and Practice of Biography and Biographical Criticism. Ed. William H. Epstein. West Lafayette, IN: Purdue UP, 1991. 217-36. Print.

Fara, Patricia. "Framing the Evidence: Scientific Biography and Portraiture." The History and Poetics of Scientific Biography. Ed. Thomas Söderqvist. Burlington, VT: Ashgate, 2007. 72-91. Print.

Fetter-Vorm, Jonathan. Trinity: A Graphic History of the First Atomic Bomb. New York: Hill and Wang, 2012. Print.

Hales, Peter B. “The Atomic Sublime." American Studies 32.1 (Spring 1991): 5-31. JStor. Web. 22 July 2014. 
Hatfield, Charles. Alternative Comics: An Emerging Literature. Jackson, MS: UP of Mississippi, 2005. Print.

Hecht, David K. “The Atomic Hero: Robert Oppenheimer and the Making of Scientific Icons in the Early Cold War." Technology and Culture 49.4 (Oct. 2008): 943-66. Print.

Hijiya, James A. "The Gita of J. Robert Oppenheimer." Proceedings of the American Philosophical Society 144.2 (June 2000): 123-66. Print.

Latour, Bruno. "Drawing Things Together." Representation in Scientific Practice. Ed. Michael E. Lynch and Steve Woolgar. Cambridge, MA: MIT P, 1990. 19-68. Print.

Latour, Bruno, and Steve Woolgar. Laboratory Life: The Social Construction of Scientific Facts. Princeton: Princeton UP, 1979. Print.

McCloud, Scott. Understanding Comics: The Invisible Art. Northampton, MA: Kitchen Sink, 1993. Print.

Miller, Frank. Sin City Library. Milwaukie, OR: Dark Horse, 2005. Print.

Monk, Ray. Inside the Centre: The Life of J. Robert Oppenheimer. London: Vintage, 2012. Print.

Nakazawa, Keiji. Barefoot Gen: A Cartoon Story of Hiroshima. Vol. 1. 1972-73. Trans. Project Gen. San Francisco: Last Gasp, 2005. Print.

Naremore, James. More than Night: Film Noir in its Contexts. 2nd ed. Berkeley: U of California P, 2008. Print.

Ottaviani, Jim, et al. Fallout: J. Robert Oppenheimer, Leo Szilard, and the Political Science of the Atomic Bomb. Ann Arbor, MI: G.T. Labs, 2001. Print.

Ottaviani, Jim, and Leland Myrick. Feynman. New York: First Second, 2011. Print.

Redniss, Lauren. Radioactive: Marie \& Pierre Curie: A Tale of Love and Fallout. New York: It Books, 2010. Print.

Rosenthal, Peggy. "The Nuclear Mushroom Cloud as Cultural Image." American Literary History 3.1 (Spring 1991): 63-92. JStor. Web. 22 July 2014.

Smith, Sidonie, and Julia Watson. Reading Autobiography: A Guide for Interpreting Life Narratives. 2nd ed. Minneapolis: U of Minnesota P, 2010. Print.

Söderqvist, Thomas. "No Genre of History Fell Under More Odium than that of Biography': The Delicate Relations between Scientific Biography and the Historiography of Science." The History and Poetics of Scientific Biography. Ed. Thomas Söderqvist. London: Ashgate, 2005. 241-62. Print.

Szasz, Ferenc Morton. Atomic Comics: Cartoonists Confront the Nuclear World. Reno, NV: U of Nevada P, 2012. Print.

Thorpe, Charles. Oppenheimer: The Tragic Intellect. Chicago: U of Chicago P, 2006. Print.

Wayne, Teddy. Interview with Jonathan Fetter-Vorm. HuffPost Books Blog. The Huffington Post. 8 Oct. 2012. Web. 30 July 2014.

Weart, Spencer R. The Rise of Nuclear Fear. Cambridge, MA: Harvard UP, 2012. Print.

Whitlock, Gillian. "Autographics: The Seeing 'I' of the Comics." Modern Fiction Studies 52.4 (Winter 2006): 965-79. Project Muse. Web. 9 Aug. 2013. 


\section{biography \\ an interdisciplinary quarterly \\ 38.1 - Winter 2015}

\section{EDITORS' InTRODUCTION}

\section{Jason Breiter, Orly Lael Netzer, Julie Rak, and Lucinda Rasmussen}

Introduction: Auto/Biography in Transit

The essays in this special issue engage with a range of issues relating to Auto/ Biography in Transit, the title of the 2014 International Auto/Biography Association (IABA) conference held in Banff, from which the issue emerged. The essays have been divided into two areas of inquiry: Documents and Displacements. Those in the first section address the status of the document as a technology of the self, or think about how cultural producers document their lives. Essays in the second section explore critical approaches and texts that signify how both the study of life writing and its objects of inquiry are themselves in transit, and have the potential to change our ideas about the field itself.

\section{Articles}

\section{DOCUMENTS}

\section{Candida Rifkind}

The Seeing Eye of Scientific Graphic Biography

This article examines two graphic biographies about Robert Oppenheimer that use visual strategies to overcome some of the narrative problems of prose scientific biography. I argue that we consider scientific graphic biography as a specific genre that installs a biographical eye (as opposed to the auto/biographical I) to explore the complex relationship between empirical knowledge and affective experience that shapes lives caught between science and politics.

\section{Terri Tomsky}

The Guantánamo Lawyers: Life Writing for the

"Courts of Public Opinion"

This article explores the strategic deployment of the life narrative genre by the lawyers of designated enemy combatants as part of the human rights activism against the unlawful detainment of prisoners at the US military prison in Guantánamo.

\section{Ella Ophir}

The Diary and the Commonplace Book: Self-Inscription in

The Note Books of a Woman Alone

The Note Books of a Woman Alone (1935), the posthumously published notebooks of an impoverished London clerk, provokes reconsideration of what counts as an individual voice. More than half the text is comprised 
Student and New Scholar Network (SNS). Her doctoral research focuses on cross-cultural Canadian literatures in English and French at the turn of the twenty-first century. Orly is a research affiliate at the Canadian Literature Centre/Centre de littérature canadienne (CLC).

Ella Ophir is an Assistant Professor of English at the University of Saskatchewan. She specializes in British and American modernist literature, and has published widely on modernist fiction, poetry, and documentary. Her recent work explores the relationship between language and power, with a particular focus on conceptions of voice.

Julie Rak is Professor and the Associate Chair of Graduate Studies at the University of Alberta. Her latest books are Boom! Manufacturing Memoir for the Popular Market (Wilfrid Laurier UP, 2013); with Anna Poletti, Identity Technologies: Constructing the Self Online (U of Wisconsin P, 2014); and with Keavy Martin, a new edition of Mini Aodla Freeman's Life Among the Quallunaat (U of Manitoba P, 2015), a memoir of Inuit life in transit.

Lucinda Rasmussen recently completed her PhD in the Department of English and Film Studies at the University of Alberta, where she currently teaches a range of first-year English courses. Her research and teaching interests include contemporary women's auto/biography, pop feminism, decolonization, and Indigenous literature.

Candida Rifkind is Associate Professor in the Department of English at the University of Winnipeg, where she specializes in graphic life narratives and Canadian popular and political writing. She is the author of Comrades and Critics: Women, Literature, and the Left in 1930s Canada (U of Toronto P, 2009), and co-editor with Linda Warley of a forthcoming collection, Canadian Graphic Life Narratives. Recent publications include articles on Guy Delisle's comics travelogue Shenzhen, the biotopographies of Seth's "picture novella" George Sprott, metabiography and black visuality in Ho Che Anderson's King, and visual nostalgias of the Canadian company town. She is currently writing a book on transnational graphic biography.

Elizabeth Rodrigues is a $\mathrm{PhD}$ candidate in English Language and Literature at the University of Michigan. Her dissertation focuses on data as an epistemological concept and aesthetic form in twentieth century US life writing. Her most recent article in Biography is "Antjie Krog and the Autobiography of Postcolonial Becoming” (37.3, Summer 2014). 